\title{
The Effect of Earnings Management and Earnings Persistence on Earnings Response Coefficient: Evidence from Indonesia
}

\author{
Suwarno \\ Universitas Muhammadiyah Gresik, Indonesia \\ E-mail: suwarno@umg.ac.id
}

Received: July 6, 2018 Accepted: October 10, 2018 Published: October 12, 2018

doi: 10.5296/jsss.v6i1.13363 URL: http://doi.org/10.5296/jsss.v6il.13363

\begin{abstract}
This study aims to examine the effect of earnings management and earnings persistence on earnings response coefficient. The sample of research is consumer sector company period 2013 - 2016 which listed in Indonesia stock exchange. The results showed that earnings management had a negative effect not significant on the income response coefficient. The earnings management will reduce the quality of earnings that will negatively reacted investors. While earnings persistence positive effect on earnings response coefficient.
\end{abstract}

Keywords: Earnings management, Earnings response coefficient, Earnings persistence

\section{Introduction}

The purpose financial statements is provide financial information useful for investors decision making. The financial statements provide useful information to assess the company's performance and predict the return on investment or resources to be allocated to the company. With financial statement information, investors can assess the company's ability to generate profits and expect a high rate of return on its investment. Because the financial performance of the company will signal to investors through the accounting profit figures published in financial reporting. however, if the financial statements show poor performance then management will do earnings management (Lin, Lo, \& Wu, 2016).

Several studies have shown a relationship of earnings management with market reaction. Market reaction can be measured using earnings response coefficient (ERC). Results of research conducted by (Hosseini, Chalestori, Hi, \& Ebrahimi, 2016) show a negative relationship between earnings management and ERC. Earnings management is a negative signal for investors, because market participants view that earnings management will reduce 
the quality of earnings. The company's earnings do not show real financial performance. Companies with higher revenues will be vulnerable to earnings management.

Research conducted by Ghosh, Gu, and Jain, (2005) showed that companies that reported sustained revenue and earnings, have high earnings quality and the level of earnings response coefficients than companies that reported sustained revenue only. Increased sustainable revenue and eranings shows the company's success in implementing its business strategy is not for earnings management. Companies can increase earnings by increasing revenue in a sustainable operation in the long term.

Earnings management and earnings persistence are factors related earnings response coefficient. Investors will assess the quality of accounting profit generated by management in managing the company. Management contracted the owner to manage the company, and aims to increase the prosperity of the owner. At some point, there will be a conflict of interest between management and owners. Management has access to more information while the owner otherwise causing asymmetry of information (Lennox \& Park, 2006).

\section{Theory and Hypothesis}

\subsection{Agency Theory}

Agency theory explains the relationship between agent and owner (Jensen \& Meckling, 1976). The owner gives the manager a contract to manage his company. Owners and managers have the same goal of increasing the value of the company. The agency theory is based on the concept of basic human behavior that sometimes behaves opportunistically. It is this opportunistic behavior that leads to agency costs. Agency costs arise because managers have access to more financial information than owners or are often called information asymmetries. So the owner to supervise and control the management in managing the company. The costs of such supervision include the cost of financial audits or corporate governance. The opportunistic behavior of managers will show good corporate performance for its own sake. Because the financial performance of the company will relate to the agreed compensation management with the owner. So managers will make earnings management to improve the quality of earnings.

\subsection{Earnings Management}

Earnings management is one of the accounting issues of interest to academics and researchers. Researchers often examine the relationship and consequences of earnings management in addition to studies examine earnings management detection techniques (Dechow, Sloan, \& Sweeney, 1995). Earnings management is a management action to make income smoothing by modifying accounting policies. Earnings management will have an impact on the quality of financial statement information. Financial statement information will be misleading to users of financial statement (Abdurrahim Ahim, 1995). Earnings management actions can be done by determining the recognition accounting policy are made, to allocate sales or expense in certain periods, and the management's discretion alone in classifying posts profit loss. One of the motivations of profit management action is the existence of management interests that are not aligned with the owner as described in the agency theory. 


\subsection{Earnings Management Affects Earnings Response Coefficient}

Earnings management is a management effort to take income smoothing action. Income smoothing action intended to make the company's financial performance appear better by the user. One form of the income smoothing is to recognize early sales and recognized expense in future periods. Research conducted by Feltham and Pae (2000) that the accrual accounting selection is related to ERC. Management expects the earnings management will give good news to the owners or investors and ultimately enhance shareholder value. (Lo, Ramos, \& Rogo, 2017). The results showed that earnings management influence earnings response coefficient (Hosseini et al., 2016). The results show that the more informed delivery of information will reduce information asymmetry (Lennox \& Park, 2006).

\section{$\mathrm{H}_{1}$ : The affects of earnings management on earnings response coefficient}

\subsection{Earnings Persistence Effect on Earnings Coefficient Response}

The efficient market hypothesis states that the market will react to the financial statement information in the capital market. Investors will respond to financial statement information published by the company. If the company's earnings quality publish information it will be immediately reacted by the market. Some studies mapping income as a component of profit-making. Is sustainable income or income that is not sustainable or both will increase the amount of earnings responce coefficient (Donnelly, 2002). Research conducted by Harikumar and Harter (1995) showed that the affect of earnings persistence on persistence rerponse coefficient.

\section{$\mathrm{H}_{2}$ : The affects of earnings persistence on earnings response coefficient}

\section{Research Method}

The population in this study are all companies listed in Indonesia Stock Exchange (BEI). The sample of research is manufacturing company of consumption sector period $2013-2016$. The sampling technique is purpose-sampling method.

\subsection{Operational Definition and Variable Measurement}

Earnings management is a management action to reduce fluctuations in earnings from one period to the previous period. Earnings management is measured by discretionary accruals developed by Jones (1991). Jones's model controls the impact of changes in the company's economic environment on non-discretionary accruals. In the modified model, non-discretionary accruals are estimates in the event period, during which the estimated earnings management period occurs. The equations used to calculate non-discretionary are as follows (Ahim, 1995):

TTAC $=$ NDACC + DACC

Where :

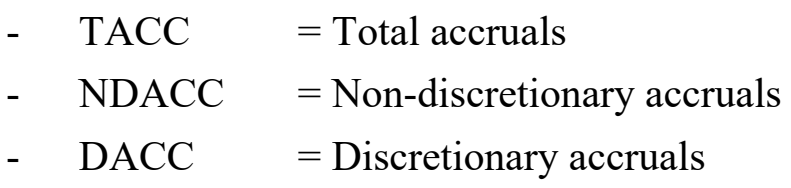

Earnings persistence is earnings quality can be used to forecast earnings in future. Earnings quality is produced from a sustainable income (Harikumar \& Harter, 1995a), (Donnelly, 
2002). The earnings persistence is formulated as follows (P. M. Dechow, Hutton, Kim, \& Sloan, 2012)

$\mathrm{E}_{\mathrm{t}}=\beta_{0}+\beta_{1} \mathrm{E}_{\mathrm{t}-1}$

Where :

- Et $=$ Earnings after tax period $\mathrm{t}$ and $\mathrm{E}_{\mathrm{t}-1}=$ Earnings after tax period $\mathrm{t}-1$

$-\beta_{1} \quad=$ If $\beta_{1}>1$ (persistent high), $\beta_{1}>0$ (indicates persistent), and If $\beta_{1} \leq 0=$ fluctuating and non-persistent earnings.

Earnings Response Coefficient (ERC) is the market reaction on unexpected earnings that is measured by the amount of abnormal stock return. ERC is calculated by the magnitude of the coefficient of the regression results between stock prices and earnings. ERC with the formula:

CARit $=\beta 0+\beta 1 \mathrm{UE}_{\mathrm{i}, \mathrm{t}}+\mathrm{e}$

Where :

- CAR $_{\text {it }} \quad=$ Cummulative abnormal return of firm $\mathrm{i}$ in period $\mathrm{t}$.

- $\mathrm{UE}_{\mathrm{i}, \mathrm{t}} \quad=$ Profit that is not expected by firm $\mathrm{i}$ in period $\mathrm{t}$; and $\beta=$ coefficient

3.2 Regression Test

Regression test aims to influence earnings management and earnings persistence on earnings response coefficient. The coefficient shows the relationship of the independent variable to the dependent variable, indicated by beta $(\beta)$ or coefficient of each independent variable. The value of the coefficient of variables approaching 1 indicates a stronger relationship and if less than one then the relationship is less strong. The regression test will use the following equation:

$\mathrm{ERC}=\alpha+\gamma 1 \mathrm{MLABA}+\gamma 2 \mathrm{PLABA}+\mathrm{e}$

Where :

- $\mathrm{ERC}=$ Earnings Response Coefficient; MLABA = Earnings Management

- PLABA = Earnings Persistence

\subsection{Hypothesis Testing}

$\mathrm{T}$ test aims to examine the effect of independent variables partially on independent variables. Hypothesis (Ha) is accepted if the significance value is $<5 \%$, meaning the earnings management and profit persistence affect earnings reponse coefficient.

\section{Conclusion}

This section will explain the results of the study, but beforehand will be explained descriptive statistics of the research sample. The research sample was 18 consumption sector companies listed on the Indonesian Stock Exchange.

Table 1. Descriptive statistics

\begin{tabular}{lllll}
\hline & Min & Max & Mean & Std. Deviation \\
\hline Earnings Response Coefficient & -0.153 & 0.243 & 0.044 & 0.075 \\
\hline Earnings Management & 0.773 & 1.310 & 0.207 & 0.604 \\
\hline Earnings Persistence & -0.068 & 0.462 & 0.0796 & 0.111 \\
\hline
\end{tabular}


Table 2. Number of Sample Earnings Management, Earnings Persistence and ERC

\begin{tabular}{llllll}
\hline \multirow{2}{*}{ Earnings Management } & $\begin{array}{l}\text { Sum Of } \\
\text { Sample }\end{array}$ & $\begin{array}{l}\text { Earnings } \\
\text { Persistence }\end{array}$ & $\begin{array}{l}\text { Sum Of } \\
\text { Sample }\end{array}$ & $\begin{array}{l}\text { Earnings } \\
\text { Response } \\
\text { Coefficient }\end{array}$ & $\begin{array}{l}\text { Sum Of } \\
\text { Sample }\end{array}$ \\
\hline Earning Management & 3 & Low Persistent & 6 & Low & 6 \\
\hline $\begin{array}{l}\text { Non Earnings } \\
\text { Management }\end{array}$ & 15 & Persistent & 2 & Medium & 12 \\
\cline { 2 - 6 } & & High Persistent & 10 & High & 1 \\
\hline
\end{tabular}

Table 2 describes the sample of companies earnings management by 3 and 15 companies did not perform earnings management. Earnings persistence is divided into three categories where 6 companies are in low persistence category, 2 companies are in persistent category and 10 companies are high persistence. Whereas ERC is divided into 3 categories where the low category is 6 companies, 12 companies are medium category and 1 company is high category.

\subsection{Test Fit Model}

To determine the effect of PLAB and PER on the ERC using the Partial Least Square (PLS) with WarpPls 3. Test results effect PER and MLABA on ERC, show in the table below:

Table 3. Model Fit and Quality Indices

\begin{tabular}{|c|c|c|}
\hline Measurement & Model fit indices & Recomendation \\
\hline Average path coefficient (APC) & 0.286 & Significant at the $\mathrm{P}<0.007$ \\
\hline Average R-squared (ARS) & 0.232 & Significant at the $\mathrm{P}<0.020$ \\
\hline Average adjusted R-squared (AARS) & 0.199 & Significant at the $\mathrm{P}<0.034$ \\
\hline Average block VIF (AVIF) & 1.218 & $\begin{array}{l}\text { acceptable if }<=5 \text {, ideally }<= \\
3.3\end{array}$ \\
\hline Average full collinearity VIF (AFVIF) & 1.054 & $\begin{array}{l}\text { acceptable if }<=5 \text {, ideally }<= \\
3.3\end{array}$ \\
\hline Tenenhaus GoF (GoF) & 0.482 & $\begin{array}{l}\mathrm{S}>=0.1, \mathrm{M}>=0.25, \mathrm{~L}>= \\
0.36\end{array}$ \\
\hline Sympson's paradox ratio (SPR) & 0.500 & $\begin{array}{l}\text { acceptable if }>=0.7 \text {, ideally }= \\
1\end{array}$ \\
\hline R-squared contribution ratio (RSCR & 0.935 & $\begin{array}{l}\text { acceptable if }>=0.9 \text {, ideally }= \\
1\end{array}$ \\
\hline Statistical suppression ratio $(\mathrm{SSR})=$ & 1.000 & acceptable if $>=0.7$ \\
\hline $\begin{array}{l}\text { Nonlinear bivariate causality direction } \\
\text { ratio (NLBCDR) }\end{array}$ & 1.000 & acceptable if $>=0.7$ \\
\hline
\end{tabular}




\section{Macrothink}

Table 3 shows the model compatibility test for the data, where the Average Path coefficient (APC), and Average R-squared (ARS), and Average adjusted R-squared (AARS) show a $\mathrm{P}$-value $<0.05$. While the value of Average block VIF $(\mathrm{AVIF}=1.218)$ indicates that there are no symptoms of multicollinearity

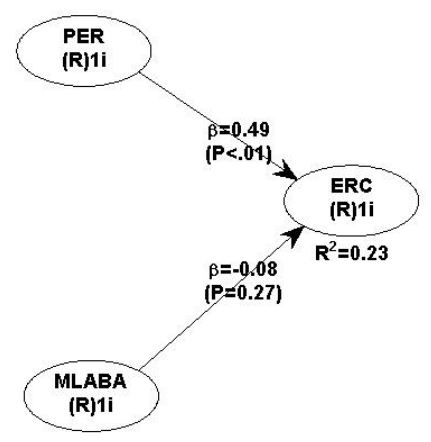

Figure 1. Corelation earnings manajement, earnings persistance and earnings response coefficient

Tabel 4. Path coeffecients and $P$ value

\begin{tabular}{llll}
\hline Path & $\boldsymbol{\beta}$ & p-value & Hypotheses \\
\hline Earnings Management & 0.08 & 0.27 & $\mathrm{H}_{1}:$ Rejected \\
\hline Earnings persistence & 0.49 & 0.01 & $\mathrm{H}_{2}:$ Accepted \\
\hline
\end{tabular}

\section{H1: Effect of Earnings Management on Earnings Response Coefficient}

Table 4 shows that the coefficient value $\left(\beta_{1}\right)$ is -0.08 with a significant value of 0.27 , so it can be concluded that the first hypothesis (H1) is rejected. This means that earnings management (MLABA) has no effect on the income response coefficient (ERC). Earnings management will affect the quality of financial statement information. So investors will react to financial statement information, this reaction can then be measured by the ERC coefficient value. Financial reports from the results of earnings management will be assessed negatively by investors. The results of this study are in accordance with the results of research conducted by Hosseini et al. (2016) that earnings management compensation has no effect on earnings response coefficients. One form of earnings management is income smoothing, where company management maintains profits from fluctuations over a certain period of time. Management actions make income smoothing, giving signals to users of financial statements that profits and revenues generated sustainably will generate positive signals for users of financial statements, especially investors. The results of research conducted by (Ghosh et al., 2005) show a positive relationship between ongoing income and income with the earnings response coefficient. 


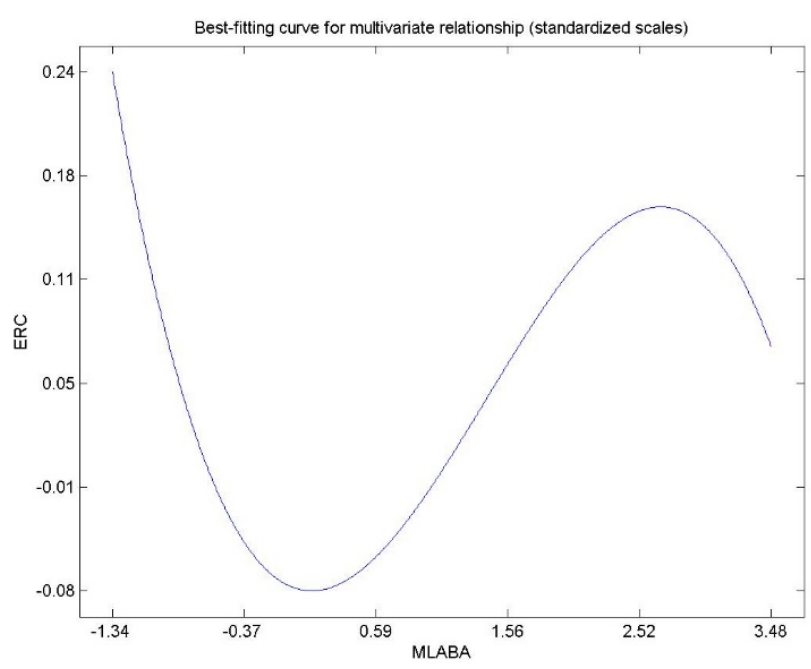

Figure 2. Curve for relationship earnings management among ERC

Figure 2 shows a plot of earnings management relationship with the ERC that the results approached the curve "S". The relationship of earnings management with ERC begins at point -1.34 where earnings management can reduce the ERC and at point 0.59 where earnings management can increase the ERC but at 0.52 will decrease the ERC. The model of the relationship between earnings management and ERC which resembles the "S" curve shows that earnings management cannot improve earnings quality.

\section{H2: Effect of Earnings Persistence on Earnings Response Coefficient.}

Table 4 above shows that the coefficient value $\left(\beta_{2}\right)$ is 0.489 with a significant value of 0.01 , so it can be concluded that the second hypothesis $\left(\mathrm{H}_{2}\right)$ is received because of the significant value $<0.5$. This means that there is influence persistensi profit (PER) to earnings response coefficient (ERC). The results of this study are in line with research conducted by (Harikumar \& Harter, 1995b) that earnings persistence effect on earnings response coeffiecient. Profits that have high persistence are profits generated from the operating income of the company or sustainable so that it will produce a quality profit compared with the profit generated from non-operating income. The higher the value of earnings persistence indicates the quality of the firm's earnings and will be in the market response. Quality profits are not generated from earnings management but because of management in executing corporate strategy. Success in running a strategy will have an impact on long-term earnings and profits. Management not only achieves short-term earnings and profits or often managers tend to behave opportunistically. Behavior of managers who tend to pursue their interests rather than owners. (Jensen \& Meckling, 1976). 


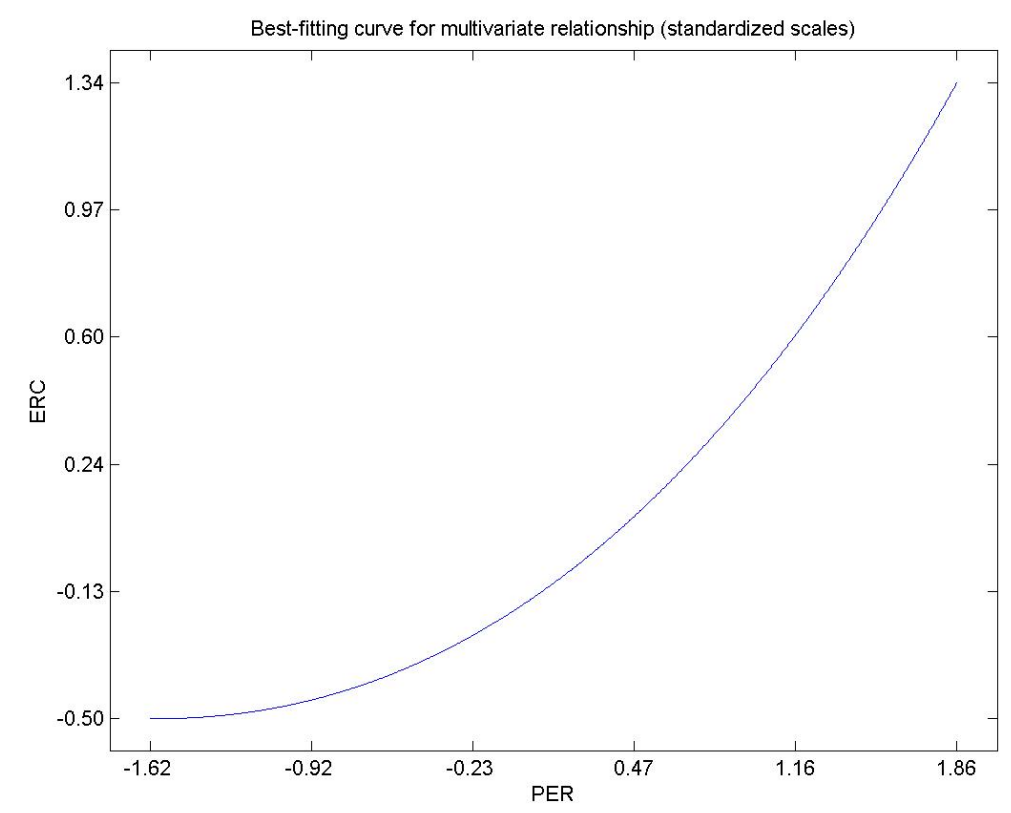

Figure 3. Curve for relationship earning persitance among ERC

Figure 3 shows the plot of the relationship between earnings persistence and ERC which results in linear. The relationship between earnings persistence and ERC starts at point -1.62 where earnings persistence will increase the ERC. The model of the relationship between earnings persistence and ERC shows that quality earnings will increase ERC.

\section{References}

Abdurrahim Ahim. (1995). Mendeteksi Earnings Management. Jurnal Akuntansi Dan Investasi, 1(2), 104-111.

Dechow, P. M., Sloan, R. G., \& Sweeney, A. P. (1995). Detecting Earnings Management. The Accounting Review, 70(2), 193-225. https://doi.org/10.2307/248303

Donnelly, R. (2002). Earnings persistence, losses and the estimation of earnings response coefficients. Abacus, 38(1), 121-133. https://doi.org/10.1111/1467-6281.00100

Feltham, G. A., \& Pae, J. (2000). Analysis of the Impact of Accounting Accruals on Earnings Uncertainty and Response Coefficients. Journal of Accounting, Auditing \& Finance, 15(3), 199-220. https://doi.org/10.1177/0148558X0001500301

Ghosh, A., Gu, Z., \& Jain, P. C. (2005). Sustained Earnings and Revenue Growth, Earnings Quality, and Earnings Response Coefficients. Review of Accounting Studies, 10(1), 33-57. https://doi.org/10.1007/s11142-004-6339-3

Harikumar, T., \& Harter, C. I. (1995). Earnings Response Coefficient and Persistence: New Evidence Using Tobin's q as a Proxy for Persistence. Journal of Accounting, Auditing \& Finance, 10(2), 401-418. https://doi.org/10.1177/0148558X9501000215

Hosseini, M., Chalestori, K. N., Hi, S. R., \& Ebrahimi, E. (2016). A Study on the Relationship between Earnings Management Incentives and Earnings Response Coefficient. Procedia Economics and Finance, 36, 232-243. https://doi.org/10.1016/S2212-5671(16)30034-X 


\section{Macrothink}

Journal of Social Science Studies

ISSN 2329-9150 2019, Vol. 6, No. 1

Jensen, M. C., \& Meckling, W. H. (1976). Theory of the firm: Managerial behavior, agency costs and ownership structure. Journal of Financial Economics, 3(4), 305-360. https://doi.org/10.1016/0304-405X(76)90026-X

Lennox, C. S., \& Park, C. W. (2006). The informativeness of earnings and management's issuance of earnings forecasts. Journal of Accounting and Economics, 42(3), 439-458. https://doi.org/10.1016/j.jacceco.2006.05.001

Lin, H.-W. W., Lo, H.-C., \& Wu, R.-S. (2016). Modeling default prediction with earnings management. Pacific-Basin Finance Journal, 40, 306-322. https://doi.org/10.1016/j.pacfin.2016.01.005

Lo, K., Ramos, F., \& Rogo, R. (2017). Earnings management and annual report readability. Journal of Accounting and Economics (Vol. 63). Elsevier. https://doi.org/10.1016/j.jacceco.2016.09.002

Martikainen, M. (1997). Accounting losses and earnings response coefficients: The impact of leverage and growth opportunities. Journal of Business Finance and Accounting, 24(2), 277-291. https://doi.org/10.1111/1468-5957.00105

\section{Copyright Disclaimer}

Copyright for this article is retained by the author(s), with first publication rights granted to the journal.

This is an open-access article distributed under the terms and conditions of the Creative Commons Attribution license (http://creativecommons.org/licenses/by/3.0/). 